\title{
Cardinal temperatures and modeling of vegetative development in guava
}

\author{
Mábele de C. Ferreira ${ }^{1}$, Fabrina B. Martins ${ }^{1}$, Gabriel W. L. Florêncio ${ }^{1}$ \& Liliana A. A. P. Pasin ${ }^{2}$ \\ ${ }^{1}$ Universidade Federal de Itajubá/Instituto de Recursos Naturais. Itajubá, MG, Brasil. E-mail: mabeleferreira@yahoo.com.br (Corresponding author) - ORCID: \\ 0000-0001-6724-7217; fabrinabm@gmail.com - ORCID: 0000-0003-0401-6168; gabrielflorencio1797@gmail.com - ORCID: 0000-0003-3510-884X \\ ${ }^{2}$ Centro Universitário de Itajubá/Núcleo de Pesquisa Institucional. Itajubá, MG, Brasil. E-mail: lapasin@gmail.com - ORCID: 0000-0003-1728-089X
}

\begin{abstract}
The aim of this study was to estimate cardinal temperatures (base, optimum, and maximum), and simulate the vegetative development of guava crop through phyllochron (linear) and Wang and Engel (nonlinear) models at the seedling phase. The experiment was conducted in Itajubá, MG, Brazil $\left(22^{\circ} 24^{\prime}\right.$ $46.43^{\prime \prime} \mathrm{S} 45^{\circ} 26^{\prime} 48.94^{\prime \prime} \mathrm{W}$ ), for two years in a completely randomized design with twelve sowing dates and five experimental units per treatment, totaling sixty experimental units. The cardinal temperatures were estimated using twelve methods described in the literature and the values were: base, $10.9^{\circ} \mathrm{C}$, optimum, 17.3 ${ }^{\circ} \mathrm{C}$ and maximum, $51.2^{\circ} \mathrm{C}$. The phyllochron model was superior to Wang and Engel's model for simulation of vegetative growth of guava, with root mean square error of 1.5 leaves.
\end{abstract}

Key words: Psidium guajava L., leaf appearance, degree days

\section{Temperaturas cardinais e modelagem do desenvolvimento vegetativo em goiabeira}

RESUMO: O objetivo deste estudo foi estimar as temperaturas cardinais (basal inferior, ótima e basal superior) e simular o desenvolvimento vegetativo da goiabeira através dos modelos filocrono (linear) e Wang e Engel (não linear) durante a fase de muda. Um experimento de campo instalado em Itajubá, MG $\left(22^{\circ} 24^{\prime} 46.43^{\prime \prime}\right.$ S $45^{\circ} 26^{\prime} 48.94^{\prime \prime} \mathrm{O}$ ) foi conduzido durante dois anos sob o delineamento inteiramente casualizado, com doze épocas de semeadura e cinco unidades experimentais por tratamento, totalizando sessenta unidades experimentais. As temperaturas cardinais foram estimadas através de doze métodos descritos na literatura e os valores foram: basal inferior, $10,9{ }^{\circ} \mathrm{C}$, ótima, $17,3^{\circ} \mathrm{C}$ e basal superior, $51,2^{\circ} \mathrm{C}$. O modelo do filocrono foi superior ao Wang e Engel na simulação do desenvolvimento vegetativo da goiabeira, com valor de raiz do quadrado médio do erro de 1,5 folhas.

Palavras-chave: Psidium guajava L., aparecimento de folhas, graus-dia 


\section{INTRODUCTION}

Guava (Psidium guajava L.) is a perennial fruit crop of family Myrtaceae. The fruits present sweet-acidified flavor and pleasant aroma, which is the major reason for its great variety of products, uses and forms of consumption (Velho et al., 2011; Campos et al., 2013). In Brazil, guava is cultivated in a wide area, reaching 20,294 hectares of land with average annual production of 460,515 tons (IBGE, 2017). In addition, due to the attractiveness of the fruit to the fauna, the species present good dispersion capacity, and is used in the recomposition of degraded areas (Silva et al., 2013).

Vegetative and reproductive development of guava is directly influenced by the air temperature (Pereira \& Kavati, 2011), whose effect represents the daily energy accumulation available for the development of the plant. Mathematically, this energy can be determined by linear functions such as the phyllochron (FIL) or nonlinear function, with Wang and Engel's model (WE) being the best known (Wang \& Engel, 1998). Both models require the inclusion of cardinal temperatures (base $(\mathrm{Tb})$, optimum (Tot), and maximum (TB)), which represent the thermal limits for the proper development of plants (Freitas et al., 2017; Callejas et al., 2014).

The FIL model assumes a linear and additive relationship with the plant's development, and is represented by the leaf appearance rate (LAR) and air temperature function, expressed by the degree days (Erpen et al., 2013; Martins et al., 2014). On the other hand, the WE model associates LAR with functions of response to temperature $[f(T)]$ such as the beta function (Martins et al., 2014; Monteiro et al., 2014). Therefore, the aim of this work was to estimate cardinal temperatures in order to evaluate and compare the simulation by phyllochron and Wang and Engel models on the vegetative development represented by LAR of guava during the seedling phase.

\section{Material ANd Methods}

The study was conducted in the experimental area of the Universidade Federal de Itajubá, in 2015 and 2016 (22 24' $46.43^{\prime \prime S}$ and $45^{\circ} 26^{\prime} 48.94^{\prime \prime}$ W, 1.050 m altitude), Itajubá, MG. The climate of this area is characterized as subtropical Cwa with dry winters and hot summers (Freitas et al., 2017).

Guava seeds were collected from six matrices located in Pedralva, MG, in two dispersion periods (2015/2016), following the recommendations for drying and storage stated by Sena \& Gariglio (2008).

The experiment was performed in a completely randomized design in twelve sowing dates, through direct method with thirty day intervals (sowing dates - E) (Freitas et al., 2017) which allowed the plants to be exposed to different meteorological conditions and five experimental units (EU) per treatment, totaling sixty EU.

Each EU consisted of two plants initially developed in an $11 \mathrm{~L}$ white polyethylene pot $(23 \mathrm{~cm}$ height, $24 \mathrm{~cm}$ upper diameter and $20 \mathrm{~cm}$ lower diameter) filled with moderate horizon Oxisol soil collected in Itajubá, MG, Brazil. The chemical characteristics were 2.50 dag $\mathrm{kg}^{-1}$ of organic matter (Walkley-Black), $0.6 \mathrm{mg} \mathrm{dm}^{-3}$ of $\mathrm{P}$ and $5.0 \mathrm{mg} \mathrm{dm}^{-3}$ of $\mathrm{K}$, obtained by Mehlich extractor 1 . About 90 days before sowing, corrections for fertility and acidity were done according to the literature (CFSEMG, 1999). This was achieved by applying $8.40 \mathrm{~g}$ simple-superphosphate (18\%), 0.256 g potassium chloride (60\%), $0.35 \mathrm{~g}$ ammonium sulfate (20\%), $6.45 \mathrm{~g}$ magnesium carbonate, and $12.20 \mathrm{~g}$ calcium carbonate. At 90-120 days after each sowing, cover fertilization was performed by applying $0.575 \mathrm{~g}$ potassium chloride and 0.575 $\mathrm{g}$ ammonium sulfate in each EU.

The EU were arranged on pallets with $15 \mathrm{~cm}$ spacing under $50 \%$ shading and positioned $2 \mathrm{~m}$ high from the soil. Except on rainy days, regular watering was performed in the afternoon, leaving each pot close to saturation to avoid water stress, which could influence LAR (Freitas et al., 2017).

Vegetative development was quantified by the weekly count of the leaves number emitted on the main stem (LN), which provided LAR during the seedling phase, which started when seedlings reached $50 \%$ emergence $(\mathrm{LN} \geq 1.0 \mathrm{~cm})$ and finished when each EU reached an average of $20 \mathrm{LN}$ (Souza \& Martins, 2014; Freitas et al., 2017). Data of daily air temperature were obtained from the automatic weather station located next to the experiment.

The first five sowing dates were used for the $\mathrm{Tb}$ estimation, since they included the lowest values of mean air temperature (Souza \& Martins, 2014); for Tot, the 12 sowing dates were used; and the two sowing dates with the highest values of mean air temperature were used for TB (Lima \& Silva, 2008; Freitas et al., 2017).

Traditional methodologies were used for the Tb estimation (Yang et al., 1995; Souza \& Martins, 2014): standard deviation in degree days (SDdd), standard deviation in days (SDd), coefficient of variation in days $(\mathrm{CVd})$, coefficient of variation in degree days (CVdd), regression coefficient (RC) and relative development $(\mathrm{RD})$; and the modified methodologies (Yang et al., 1995): SDddmod, SDdmod, CVddmod, RCmod. All methodologies were based on the standard deviation of accumulated growing degree days (GDD, ${ }^{\circ} \mathrm{C}$ day), obtained by the following expression (Souza \& Martins, 2014) (Eq. 1):

$$
\mathrm{GDD}=\sum_{\mathrm{i}=1}^{\mathrm{n}} \mathrm{Tmed}-\mathrm{Tb}, \text { if } \mathrm{Tmed}<\mathrm{Tb}, \mathrm{Tmed}=\mathrm{Tb}
$$

where:

GDD - Growing degree days;

Tmed - medium air temperature $\left({ }^{\circ} \mathrm{C}\right)$ obtained by the arithmetic mean data from the automatic weather station (recorded every $10 \mathrm{~min}$ )

$\mathrm{Tb}$ - base temperature;

i - emergence date; and,

$\mathrm{n} \quad$ - end date of the seedling phase.

For the GDD calculation, a Tb series ranging from 0 to $20^{\circ} \mathrm{C}$ was used in $0.5^{\circ} \mathrm{C}$ intervals. The final $\mathrm{Tb}$ value was obtained by the arithmetic mean of $\mathrm{Tb}$ values observed among the ten estimation methods (Souza \& Martins, 2014).

Tot was estimated as recommended by Lisboa et al. (2012) and Freitas et al. (2017) based on the arithmetic mean of air 
temperature of the sowing date with the greatest vegetative development, consequently, the lowest phyllochron. The phyllochron was determined for each sowing date and EU. It was calculated from the emergence date by the inverse of the linear regression coefficient between LN and GDD using the Tb estimated value. The obtained values were submitted to analysis of variance followed by means comparison by Scott-Knott's test $(\alpha=0.05)$. All tests were performed with the statistical software Sisvar 5.3 (Ferreira, 2011).

The modified methodology by Lima \& Silva (2008) was used for estimating TB considering TB $>$ Tmed $>$ Tb, through the following conditions (Eqs. 2 to 12):

$$
\begin{aligned}
& \mathrm{A}=\mathrm{N}_{2} \mathrm{TM}_{1} \mathrm{TM}_{2}-\mathrm{N}_{2} \mathrm{TM}_{2} \mathrm{Tm} \\
& \mathrm{B}=\mathrm{N}_{1} \mathrm{TM}_{1} \mathrm{TM}_{2}+\mathrm{N}_{1} \mathrm{TM}_{1} \mathrm{Tm}_{2} \\
& \mathrm{C}=\left(-\mathrm{TM}_{1}+\mathrm{Tm}_{1}\right)\left(-\mathrm{TM}_{2}+\mathrm{Tm}_{2}\right) \\
& \mathrm{D}=\mathrm{N}_{1} \mathrm{Tm}_{2}^{2} \mathrm{~N}_{2}-2 \mathrm{Tm}_{2} \mathrm{~N}_{1} \mathrm{~N}_{2} \mathrm{~Tb}-\mathrm{Tm}_{2} \mathrm{Tm}_{1} \mathrm{~N}_{1}^{2} \\
& \mathrm{E}=-\mathrm{Tm}_{2} \mathrm{TM}_{1} \mathrm{~N}_{1}^{2}+\mathrm{N}_{2}^{2} \mathrm{TM}_{1} \mathrm{Tm}_{2}- \\
& -\mathrm{Tm}_{1} \mathrm{~N}_{2}^{2} \mathrm{Tm}_{2}+2 \mathrm{Tm}_{2} \mathrm{~N}_{2}^{2} \mathrm{~Tb} \\
& \mathrm{~F}=\mathrm{Tm}_{1} \mathrm{~N}_{1}^{2} \mathrm{TM}_{2}-2 \mathrm{~N}_{2}^{2} \mathrm{TM} \mathrm{Tb}-2 \mathrm{~N}_{1}^{2} \mathrm{TM}_{2} \mathrm{~Tb} \\
& \mathrm{G}=\mathrm{TM}_{1} \mathrm{~N}_{1}^{2} \mathrm{TM}_{2}+\mathrm{Tm}_{1}^{2} \mathrm{~N}_{2} \mathrm{~N}_{1}-2 \mathrm{Tm}_{1} \mathrm{~N}_{2} \mathrm{~N}_{1} \mathrm{~Tb} \\
& \mathrm{H}=2 \mathrm{Tm} \mathrm{m}_{1} \mathrm{~N}_{2} \mathrm{~Tb}+2 \mathrm{~N}_{1} \mathrm{TM}_{2} \mathrm{~N}_{2} \mathrm{~Tb}+2 \mathrm{~N}_{2} \mathrm{TM}_{1} \mathrm{~N}_{1} \mathrm{~Tb} \\
& \mathrm{I}=-2 \mathrm{~N}_{2} \mathrm{TM}_{1} \mathrm{~N}_{1} \mathrm{TM}_{2}+\mathrm{N}_{2}^{2} \mathrm{TM}_{1} \mathrm{TM}_{2}-\mathrm{Tm}_{1} \mathrm{~N}_{2}^{2} \mathrm{TM}_{2} \\
& \mathrm{~J}=-\mathrm{N}_{1} \mathrm{TM}_{2}+\mathrm{N}_{1} \mathrm{Tm}_{2}+\mathrm{N}_{2} \mathrm{TM}_{1}-\mathrm{N}_{2} \mathrm{Tm}_{1} \\
& \mathrm{~TB}=\frac{\mathrm{A}+\mathrm{B} \pm \sqrt{\mathrm{C}(\mathrm{D}+\mathrm{E}+\mathrm{F}+\mathrm{G}+\mathrm{H}+\mathrm{I})}}{\mathrm{J}}
\end{aligned}
$$

where:

$\mathrm{N}_{1}$ and $\mathrm{N}_{2}$ - duration of the seedling phase, which extends from $50 \%$ of emergence to the end of the seedling phase, for the two sowing dates with the highest values of mean air temperature;

$\mathrm{TM}_{1}$ and $\mathrm{TM}_{2}$ - maximum air temperatures of the two sowing dates; and,

$\mathrm{Tm}_{1}$ and $\mathrm{Tm}_{2}-$ minimum air temperatures.

The following two models were used to simulate the development: phyllochron (FIL) and Wang and Engel (WE); and the simulation was performed in two stages (Martins et al., 2014). The first stage was related to the adjustment of the coefficients to the models FIL and LARmax (data from E1 to E5), and the second evaluated the performance (data from E6 to E12).
In the FIL model, LN was obtained by (Eq. 13):

$$
\mathrm{LN}=\frac{\mathrm{GDD}}{\overline{\mathrm{FIL}}}
$$

where:

LN - leaf number;

$\overline{\text { FIL }}$ - coefficient of the model given by the arithmetic mean of the linear regression coefficients between the observed mean LN (average of EU from E1 to E5) and GDD for each sowing date (E1 to E5); and,

GDD - obtained by the sum of degree days (DD) (Martins et al., 2014): when $\mathrm{Tb} \leq$ Tmed $\leq$ Tot: $\mathrm{DD}=$ Tmed $-\mathrm{Tb} 1$ day; when Tot $<$ Tmed $\leq$ TB: DD $=($ Tot $-\mathrm{Tb})[(\mathrm{TB}-\mathrm{Tmed}) /(\mathrm{TB}-$ Tot)] 1 day.

In the WE model, $\mathrm{LN}$ is obtained according to Erpen et al. (2013) (Eq. 14):

$\mathrm{LN}=\sum_{\mathrm{i}=1}^{\mathrm{n}} \mathrm{LAR}($ leaves $)$, where in $\mathrm{LAR}=\mathrm{LAR}_{\max } \mathrm{f}(\mathrm{T})$

where:

LAR - daily leaves appearance rate (leaves day ${ }^{-1}$ );

$\mathrm{LAR}_{\text {max }}$ - maximum daily leaf appearance rate (leaves day ${ }^{-1}$ ); and,

$f(T)$ - temperature function, given by:

$$
f(T)=\frac{\left[2\left(T_{\text {med }}-T B\right)^{\alpha}(\text { Tot }-T b)^{\alpha}-(\text { Tmed }-T b)^{2 \alpha}\right]}{(\text { Tot }-T b)^{2 \alpha}}
$$

when: $\mathrm{Tb} \leq \mathrm{T}_{\text {med }} \leq \mathrm{TB}$, and $\mathrm{f}(\mathrm{T})=0$ : when $\mathrm{Tmed}<\mathrm{Tb}$ and Tmed > TB;

where:

a - coefficient of $\mathrm{f}(\mathrm{T})$ :

$$
\alpha=\frac{\ln 2}{\ln \left[\frac{(\mathrm{TB}-\mathrm{Tb})}{(\mathrm{Tot}-\mathrm{Tb})}\right]}
$$

i - emergence date and beginning of simulation; and, $\mathrm{n} \quad$ - end date of the seedling phase.

The LARmax coefficient was estimated through nonlinear regressions between accumulated $\mathrm{LN}$ as a function of the accumulated values of $f(T)$ (data from E1 to E5). The value of LARmax was considered as the value obtained from the regression with the lowest value of the mean square error (MSE) (Martins et al., 2014). The nonlinear estimation procedure of the Statistica ${ }^{\circledR}$ software (Statsoft Inc., 2008) applied the Gauss-Newton variant, using the ordinary least squares method.

The models performance were assessed by root mean square error (RMSE), BIAS, and correlation coefficient (r) (Eqs. 15, 16 and 17): 


$$
\begin{gathered}
\text { RMSE }=\left[\frac{\sum_{\mathrm{i}=1}^{\mathrm{n}}\left(\mathrm{LN}_{\mathrm{est}}-\mathrm{LN}_{\mathrm{obs}}\right)^{2}}{\mathrm{n}}\right]^{0.5} \\
\mathrm{BIAS}=\frac{\left[\sum_{\mathrm{i}=1}^{\mathrm{n}} \mathrm{LN}_{\mathrm{est}}-\sum_{\mathrm{i}=1}^{\mathrm{n}} \mathrm{LN}_{\mathrm{obs}}\right]}{\sum_{\mathrm{i}=1}^{\mathrm{n}} \mathrm{LN}_{\mathrm{obs}}} \\
\mathrm{r}=\frac{\sum_{\mathrm{i}=1}^{\mathrm{n}}\left(\mathrm{LN}_{\mathrm{obs}}-\overline{\mathrm{LN}_{\mathrm{obs}}}\right)\left(\mathrm{LN}_{\mathrm{est}}-\overline{\mathrm{LN}_{\mathrm{est}}}\right)}{\left\{\left[\sum_{\mathrm{i}=1}^{\mathrm{n}}\left(\mathrm{LN}_{\mathrm{obs}}-\overline{\mathrm{LN}_{\mathrm{obs}}}\right)^{2}\right]\left[\left(\mathrm{LN}_{\mathrm{est}}-\overline{\mathrm{LN}_{\mathrm{est}}}\right)^{2}\right]\right\}^{0.5}}
\end{gathered}
$$

where:

$\mathrm{LN}_{\text {est }}$ - leaf number simulated by the FIL and WE models;

$\mathrm{LN}_{\mathrm{obs}}$ - leaf number observed; $\mathrm{n}$ - observations data;

$\overline{\mathrm{LN}_{\mathrm{obs}}}$ - observed LN mean; and,

$\overline{\mathrm{LN}_{\text {est }}}$ - LN mean simulated by the FIL and WE models.

In addition, normality and homogeneity were tested using Bartlett's test and the significance of the deviations of estimated LN was assessed using the F test (Martins et al., 2014). All tests were performed for the estimated LN by FIL and WE.

\section{Results AND Discussion}

During the 12 sowing dates, air temperature ranged from $2.3^{\circ} \mathrm{C}$ (minimum value observed in $\mathrm{E} 9, \mathrm{E} 10, \mathrm{E} 11$ and $\mathrm{E} 12$ ) to $35.7^{\circ} \mathrm{C}$ (maximum value observed in E1, E2, E3, E4, E5 and E6). These variations influenced LAR in guava crop at the seedling phase and the sowing dates, which is important in the estimation of cardinal temperatures, coefficients and the evaluation of models in the simulation of LN (Erpen et al., 2013; Martins et al., 2014; Freitas et al., 2017).

A tendency of decrease in the duration of the seedling phase in the dates with higher temperatures was observed, justifying the choice of the first five dates for the estimation of $\mathrm{Tb}$. However, E6 presented a long duration (141 days) even in high air temperature conditions, justifying the choice of this date for the estimation of TB, while E7 was chosen because of the higher mean air temperature (Table 1).

There was similarity between $\mathrm{Tb}$ values estimated for SDd, $\mathrm{CVd}, \mathrm{CVdd}$ and $\mathrm{CVdd}_{\bmod }\left(10^{\circ} \mathrm{C}\right), \mathrm{RC}_{\bmod }\left(10.4^{\circ} \mathrm{C}\right), \mathrm{RC}\left(10.5^{\circ} \mathrm{C}\right)$ and $\mathrm{RD}\left(10.9^{\circ} \mathrm{C}\right)$ and small difference $\mathrm{SDd}_{\text {mod }}\left(15.7^{\circ} \mathrm{C}\right)$, which is consistent in estimating $\mathrm{Tb}$ for guava. On the other hand, the methods $\mathrm{SDdd}\left(20^{\circ} \mathrm{C}\right)$ and $\mathrm{SDd}_{\text {mod }}\left(4^{\circ} \mathrm{C}\right)$ were inconsistent in estimating $\mathrm{Tb}$. Values of $\mathrm{Tb} \leq 6.5^{\circ} \mathrm{C}$ and $\geq 20^{\circ} \mathrm{C}$ are not realistic as the species occur spontaneously in tropical and subtropical climates, where the average temperature is above $6.5^{\circ} \mathrm{C}$ (Pereira \& Kavati, 2011). $\mathrm{Tb} \geq 20^{\circ} \mathrm{C}$ should be discarded following the recommendations of Lago et al. (2009) and Souza \& Martins (2014), because these values differ considerably from the values reported for the perennial species studied in this region (Freitas et al., 2017).

$\mathrm{Tb}=10.9^{\circ} \mathrm{C}$ estimated for the vegetative development of guava seedlings was consistent and similar to the values of other tropical and subtropical perennial species such as Eucalyptus grandis $\left(10^{\circ} \mathrm{C}\right)$ (Martins et al., 2007) and Eucalyptus urophylla $\left(11.5^{\circ} \mathrm{C}\right)$ (Freitas et al., 2017), coffee cultivars Acaiá Cerrado MG-1474 and Rubi MG-1192 (12.9 $\left.{ }^{\circ} \mathrm{C}\right)$ (Lima \& Silva, 2008), and for Purple mango $\left(10.6^{\circ} \mathrm{C}\right)$ (Callejas et al., 2014).

Optimum temperature (Tot) was obtained indirectly by the phyllochron variable, being significant $(\mathrm{p} \leq 0.05)$ for the sowing dates, indicating that its estimation can be performed through the methodology used by Lisboa et al. (2012) and Freitas et al. (2017). The phyllochron was smaller, and consequently, the development was higher at $\mathrm{E} 12\left(23.24^{\circ} \mathrm{C}\right.$ day leaf $\left.{ }^{-1}\right)($ Table 2). In E5, E3, E1, E4 and E2 (in order of magnitude), the reverse occurred, indicating that guava develops better under meteorological conditions similar to those observed in E12. The Tot, obtained by arithmetic mean of air temperature of the E12, resulted in a temperature of $17.3^{\circ} \mathrm{C}$.

The Tot $\left(17.3^{\circ} \mathrm{C}\right)$ can be considered inferior especially when compared to tropical perennial species such as Adenanthera pavonina $\left(24.4^{\circ} \mathrm{C}\right)$, Cassia fistula $\left(24.9^{\circ} \mathrm{C}\right)$, Hymenolobium petraeum $\left(24.9^{\circ} \mathrm{C}\right.$ ), and Parkia pendula $\left(25.1^{\circ} \mathrm{C}\right.$ ) (Monteiro et al., 2014). However, this value is similar to that of other tropical perennial species such as Corymbia citriodora and Eucalyptus urophylla $\left(17.1^{\circ} \mathrm{C}\right)$ (Freitas et al., 2017), which also belong to the family Myrtaceae. A probable justificative for this Tot value is the atypical occurrence of air temperatures in the period

\begin{tabular}{|c|c|c|c|c|c|c|}
\hline \multirow{2}{*}{$\begin{array}{c}\text { Sowing date } \\
\text { (month/day/year) }\end{array}$} & \multirow{2}{*}{$\begin{array}{c}\text { Seedling } \\
\text { emergence * } \\
\text { (month/day/year) }\end{array}$} & \multirow{2}{*}{$\begin{array}{c}\text { End of the seedling } \\
\text { phase ** } \\
\text { (month/day/year) }\end{array}$} & \multirow{2}{*}{$\begin{array}{l}\text { Seedling phase } \\
\text { duration (days) }\end{array}$} & \multicolumn{3}{|c|}{ Air temperature ( $\left.{ }^{\circ} \mathrm{C}\right)$} \\
\hline & & & & Minimum $^{\star * *}$ & Medium*** & Maximum*** \\
\hline $\mathrm{E} 1,05 / 12 / 2015$ & $06 / 15 / 2015$ & $12 / 23 / 2015$ & 192 & 15.0 & 20.4 & 27.6 \\
\hline E2, 06/12/2015 & 07/17/2015 & $12 / 30 / 2015$ & 167 & 15.8 & 21.2 & 28.3 \\
\hline E3, 07/10/2015 & 08/05/2015 & 01/27/2016 & 176 & 16.7 & 21.9 & 28.8 \\
\hline$E 4,08 / 11 / 2015$ & 09/04/2015 & $01 / 16 / 2016$ & 135 & 17.7 & 22.6 & 29.1 \\
\hline E5, 09/10/2015 & 09/30/2015 & 03/09/2016 & 162 & 18.3 & 23.0 & 29.4 \\
\hline$E 6,10 / 09 / 2015$ & $10 / 28 / 2015$ & $03 / 16 / 2016$ & 141 & 18.2 & 23.0 & 29.3 \\
\hline$E 7,11 / 13 / 2015$ & $12 / 04 / 2015$ & $04 / 07 / 2016$ & 126 & 18.0 & 22.6 & 29.0 \\
\hline$E 8,12 / 11 / 2015$ & $12 / 30 / 2015$ & $05 / 12 / 2016$ & 135 & 16.9 & 22.0 & 28.7 \\
\hline E9, 01/12/2016 & 02/02/2016 & $06 / 23 / 2016$ & 143 & 14.7 & 20.1 & 27.2 \\
\hline$E 10,02 / 11 / 2016$ & $02 / 29 / 2016$ & $07 / 21 / 2016$ & 144 & 12.8 & 18.6 & 26.2 \\
\hline $\mathrm{E} 11,03 / 11 / 2016$ & $03 / 30 / 2016$ & $08 / 25 / 2016$ & 149 & 11.3 & 17.6 & 25.9 \\
\hline $\mathrm{E} 12,04 / 12 / 2016$ & $04 / 28 / 2016$ & $09 / 22 / 2016$ & 154 & 10.6 & 17.3 & 25.7 \\
\hline
\end{tabular}

Table 1. Sowing dates, emergence, end and duration of the seedling phases and the air temperature characterization during twelve sowing dates for guava crop, Itajubá (MG, Brazil, 2015/2016).

${ }^{*}$ The emergence date was the day that $50 \%$ of the seedlings became visible above the ground; ${ }^{*}$ The end of the seedling phase was considered when each experimental unit reached, on average, 20 leaves; ${ }^{* *}$ Values obtained by arithmetic means of minimum, medium and maximum air temperatures. 
Table 2. Pphyllochron means $\left({ }^{\circ} \mathrm{C} \mathrm{d} \mathrm{leaf}^{-1}\right)$ for the 12 sowing dates of guava, Itajubá

\begin{tabular}{|cc|}
\hline Sowing date & Phyllochron $\left({ }^{\circ} \mathrm{C}\right.$ d leat $\left.{ }^{-1}\right)$ \\
\hline E1 & $93.57 \mathrm{~b}$ \\
E2 & $82.14 \mathrm{C}$ \\
E3 & $106.60 \mathrm{a}$ \\
E4 & $88.59 \mathrm{~b}$ \\
\hline E5 & $115.53 \mathrm{a}$ \\
E6 & $93.98 \mathrm{~b}$ \\
\hline E7 & $76.06 \mathrm{C}$ \\
\hline E8 & $76.86 \mathrm{c}$ \\
\hline E1 & $62.20 \mathrm{~d}$ \\
\hline E11 & $44.49 \mathrm{e}$ \\
\hline E12 & $49.60 \mathrm{e}$ \\
\hline Mean & $23.24 \mathrm{f}$ \\
\hline
\end{tabular}

Means followed by the same letter do not differ among themselves by the Scott-Knott test $(\alpha=0.05)$

of greatest development $\left(\mathrm{E} 12,17.2^{\circ} \mathrm{C}\right)$, which is lower than climatic means for Itajubá in this period (between 20.1 and 21 ${ }^{\circ} \mathrm{C}$ ) (Garcia et al., 2018). However, since guava is commercially explored and cultivated in several countries, there are records on the ideal temperature range for its cultivation, with values ranging between $25-28$ and $20-30{ }^{\circ} \mathrm{C}$. Nonetheless, there is no specification on the exact Tot value, neither is there any difference among the development stages. This emphasizes the importance of estimating Tot for guava in the seedling phase.

The estimated TB value $=51.2{ }^{\circ} \mathrm{C}$ for guava was higher than for tropical perennial species such as Parkia pendula $\left(40.6{ }^{\circ} \mathrm{C}\right)$ (Monteiro al., 2014), Corymbia citriodora (41.3 ${ }^{\circ} \mathrm{C}$ ) and Eucalyptus urophylla $\left(40.5^{\circ} \mathrm{C}\right)$ (Freitas et al., 2017). Despite this, the value corroborates with the characteristics of the species with good adaptability to high air temperature conditions (Pereira \& Kavati, 2011), and there are indications that the plant can tolerate temperatures close to $46^{\circ} \mathrm{C}$ during vegetative development. High TB values are expected because the maximum temperature limit impairs the metabolic processes of the plant (Freitas et al., 2017).

With the estimated values of $\mathrm{Tb}$, Tot and $\mathrm{TB}$, it was possible to adjust the coefficients and simulate the vegetative development of guava through FIL and WE models. The coefficient value (FIL) of the FIL model was $=43.10{ }^{\circ} \mathrm{C}$ day by leaf and the coefficient "LAR max" of the WE model was = 0.1086 leaves $\mathrm{d}^{-1}$.

The FIL model performed better than the WE model at all sowing dates, with a small underestimation of LN in the region $>15$, mainly at E10. At E10, there was a combination of high temperature conditions and above average precipitation, which may have increased leaf appearance rate, although not captured by the simulation models, consequently generating an underestimation of LN simulation as observed by Erpen et al. (2013).

In addition, Bartlett's test showed that variance, represented by the standard deviation in Table 3, between the observed and simulated LN by FIL and WE was not significant. This indicates that the simulations followed the assumptions of normality and homogeneity, which is desirable from the biological and statistical point of view (Martins \& Streck, 2007). In addition, there was no statistical difference between the deviations in both models.
Table 3. Performance, standard deviation (SD), and mean square error (MSE) of the phyllochron (FIL) and Wang and Engel (WE) models for the simulation of leaf appearance in guava from E6 to E12, Itajubá (MG, Brazil, 2015/2016).

\begin{tabular}{|c|c|c|c|c|c|c|c|c|}
\hline \multirow{2}{*}{$\begin{array}{l}\text { Sowing } \\
\text { date }\end{array}$} & \multirow{2}{*}{$\begin{array}{c}\text { Simulation } \\
\text { model }\end{array}$} & \multicolumn{7}{|c|}{ Tests } \\
\hline & & RMSE & BIAS & $r$ & SD & $\mathbf{S D}_{\text {obs }}$ & MSE & $F$ \\
\hline \multirow{2}{*}{ E6 } & FIL & 0.5995 & 0.0145 & 0.9941 & $4.62^{\mathrm{ns}}$ & \multirow{2}{*}{4.92} & 0.36 & ns \\
\hline & WE & 2.1374 & -0.1757 & 0.9941 & $3.74^{\text {ns }}$ & & 4.57 & $\mathrm{~ns}$ \\
\hline \multirow{2}{*}{ E7 } & FIL & 6223 & -0.1101 & 0.9963 & $4.40^{\text {ns }}$ & \multirow{2}{*}{5.59} & 2.63 & ns \\
\hline & WE & 3.1595 & -0.2595 & 0.9962 & $3.66^{\text {ns }}$ & & 9.98 & ns \\
\hline \multirow{2}{*}{ E8 } & FIL & 1.6163 & -0.1207 & 0.9971 & $4.70^{\text {ns }}$ & & 2.61 & ns \\
\hline & WE & 3703 & -0.2710 & 0.9971 & $3.89^{\text {ns }}$ & & 11.36 & ns \\
\hline \multirow{2}{*}{ E9 } & FIL & 9433 & -0.1362 & 0.9956 & $5.02^{\text {ns }}$ & \multirow{2}{*}{6.07} & 3.78 & ns \\
\hline & WE & 8241 & -0.2857 & 0.9959 & $4.14^{\mathrm{ns}}$ & & 14.62 & ns \\
\hline \multirow{2}{*}{ E10 } & FIL & 3739 & -0.1455 & 0.9927 & $4.44^{\text {ns }}$ & \multirow{2}{*}{5.92} & 5.64 & ns \\
\hline & WE & 1729 & -0.2901 & 0.9910 & $3.80^{\text {ns }}$ & & 17.41 & ns \\
\hline \multirow{2}{*}{ E11 } & FIL & 8735 & -0.0222 & 0.9846 & $4.79^{\text {ns }}$ & \multirow{2}{*}{4.94} & 0.76 & ns \\
\hline & WE & 2.0926 & -0.1739 & 0.9994 & $4.19^{\text {ns }}$ & & 4.38 & ns \\
\hline \multirow{2}{*}{ E12 } & FIL & 5002 & 0.0867 & 0.9947 & $4.18^{\text {ns }}$ & \multirow{2}{*}{5.34} & 2.25 & ns \\
\hline & WE & 1.8837 & -0.0660 & 0.9916 & $3.62^{\text {ns }}$ & & 3.55 & ns \\
\hline
\end{tabular}

RMSE-Root mean square error, refers to the mean error of the model and the lower its value, the better the model; BIAS - Indicates the tendency, the closer it is to zero, the better the model; $r$-Correlation coefficient, quantifies the degree of association, the closer it is to 1 (positive or negative) the greater the relationship between the simulated and observed LN and the better the model; SD - Standard deviation of the observed LN; ns - Not significant at 0.05 probability by the Bartlett's test, which compares the observed and simulated variance, and by F test, which compares the MSE of both models (FIL and WE).

The overall RMSE of the FIL (1.5 leaves) is lower than the WE (2.95 leaves), demonstrating the superiority of the FIL in the simulation of guava vegetative development. In practice, RMSE $=1.5$ leaves represents an error inferior to 7 days, since guava produces a pair of leaves per week. This error is considered small and acceptable and does not impact on the simulation or prediction of other processes based on the LN, including the determination of the seedling phase end and the planting date in the field (Streck et al., 2007; Martins et al., 2014) (Figure 1).

Even though nonlinear development models, such as WE, are preferred because they describe the development of plants (Erpen et al., 2013) in a more realistic way and are applied under conditions of great temperature variation (Martins et al., 2014), the FIL model showed superior performance in the simulation of LN for guava. Similar results were obtained by Martins et al. (2014) in the LN simulation and duration of the seedling phase for 'MGS ASC315' olive cultivar, by Monteiro et al. (2014) in seedlings of Adenanthera pavonina L., Cassia fistula L., Hymenolobium petraeum Ducke and Parkia pendula Willd., by Erpen et al. (2013) in the vegetative development of sweet potato, and Streck et al. (2007) in the vegetative and reproductive development of rice genotypes. The main advantages of FIL are: simplicity, ease of application, reduced number of parameters and ease in obtaining the input variables (Erpen et al., 2013; Martins et al., 2014).

The cardinal temperature estimation $(10.9,17.3$ and 51.2 ${ }^{\circ} \mathrm{C}$ ) allowed the vegetative development simulation of guava in the seedling phase and the choice of FIL as the best model, which should be used in the evaluation of guava response in scenarios of climatic changes (Cocco et al., 2016; Erpen et al., 2013). Although information on the three cardinal temperatures for fruit tree species are scarce, it is useful to know the needs of such species under different meteorological conditions and their adaptations to the climatic conditions of cultivation (Souza \& Martins, 2014). 


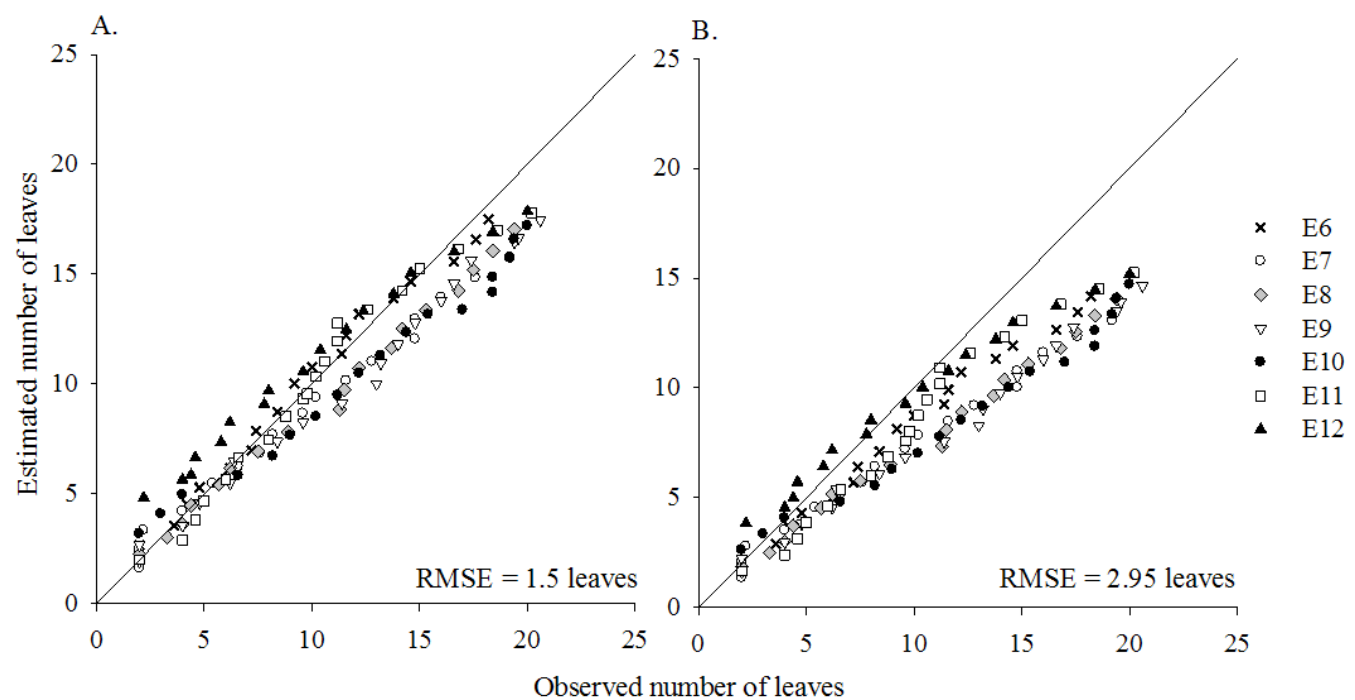

Figure 1. Observed number of leaves versus simulated by FIL (A) and WE (B) models for guava, Itajubá (MG, Brazil, 2015/2016)

\section{Conclusions}

1. The estimated cardinal temperatures for the vegetative development of guava in the seedling phase were: base $=10.9$ ${ }^{\circ} \mathrm{C}$, optimum $=17.3^{\circ} \mathrm{C}$ and maximum $=51.2{ }^{\circ} \mathrm{C}$.

2. The phyllochron model (linear) is superior in the simulation of the vegetative development of guava in the seedling phase.

\section{ACKNowledgements}

The Minas Gerais Research Support Foundation (FAPEMIG) for financial support, and Coordination for the Improvement of Higher Education Personnel (Capes, process numbers 1489491 and 1827878 ) for granting scholarships to the $1^{\text {st }}$ and $3^{\text {rd }}$ authors.

\section{Literature Cited}

Callejas, I. J. A.; Neves, G. A. R.; Tavares, A. de S.; Moura, I. B. de; Lima, E. A. de. Determinação das temperaturas cardinais da manga cultivar Roxa através de simulação computacional utilizando um modelo não linear. Ambiência, v.10, p.97-110, 2014.

Campos, B. M.; Viana, A. P.; Quintal, S. S. R.; Gonçalves, L. S. A.; Pessanha, P. G. de O. Quantificação da divergência genética entre acessos de goiabeira por meio da estratégia WARD-MLM. Revista Brasileira de Fruticultura, v.35, p.571-578, 2013. https:// doi.org/10.1590/S0100-29452013000200028

CFSEMG - Comissão de Fertilidade do Solo do Estado de Minas Gerais. Recomendações para o uso de corretivos e fertilizantes em Minas Gerais: 5. aproximação. Viçosa: Comissão de Fertilidade do Solo do Estado de Minas Gerais, 1999. p.289-302.

Cocco, K. L. T.; Schmidt, D.; Caron, B. O.; Souza, V. Q. de; Fontana, D. C.; Paula, G. M. de. Estimated phyllochron in low tunnel cultivated strawberry cultivars. Ciência Rural, v.46, p.1546-1552, 2016. https://doi.org/10.1590/0103-8478cr20150708

Erpen, L.; Streck, N. A.; Uhlmann, L. O.; Langner, J. A.; Winck, J. E. M.; Gabriel, L. F. Estimativa das temperaturas cardinais e modelagem do desenvolvimento vegetativo em batata-doce. Revista Brasileira de Engenharia Agrícola e Ambiental, v.17, p.1230-1238, 2013. https://doi.org/10.1590/S1415-43662013001100015
Ferreira, D. F. Sisvar: A computer statistical analysis system. Ciência e Agrotecnologia, v.35, p.1039-1042, 2011. https://doi.org/10.1590/ S1413-70542011000600001

Freitas, C. H. de; Martins, F. B.; Abreu, M. C. Cardinal temperatures for the leaf development of Corymbia citriodora and Eucalyptus urophylla seedlings. Pesquisa Agropecuária Brasileira, v.52, p.283292, 2017. https://doi.org/10.1590/s0100-204x2017000500001

Garcia, S. R.; Santos, D. F. dos; Martins, F. B.; Torres, R. R. Aspectos climatológicos associados ao cultivo da oliveira (Olea europaea L.) em Minas Gerais. Revista Brasileira de Climatologia, v.22, p.188-209, 2018. https://doi.org/10.5380/abclima.v22i0.56825

IBGE - Instituto Brasileiro de Geografia e Estatística. Produção agrícola municipal. 2017. Available on: <https://sidra.ibge.gov. br/pesquisa/pam/tabelas $>$. Accessed on: Jul. 2019.

Lago, I.; Streck, N. A.; Carvalho, M. P.; Fagundes, L. K.; Paula, G. M. de; Lopes, S. J. Estimativa da temperatura base do subperíodo emergência-diferenciação da panícula em arroz cultivado e arroz vermelho. Revista Ceres, v.56, p.288-295, 2009.

Lima, E. P.; Silva, E. L. da. Temperatura base, coeficientes de cultura e graus-dia para cafeeiro arábica em fase de implantação. Revista Brasileira de Engenharia Agrícola e Ambiental, v.12, p.266-273, 2008. https://doi.org/10.1590/S1415-43662008000300007

Lisboa, P. M. M.; Martins, F. B.; Alvarenga, M. I. N.; Vieira Neto, J.; Reis, D. F. Desenvolvimento vegetativo de duas cultivares de oliveira na fase de muda. Ciência Rural, v.42, p.1556-1562, 2012. https://doi.org/10.1590/S0103-84782012000900007

Martins, F. B.; Pereira, R. A. A.; Pinheiro, M. V. M.; Abreu, M. C. Desenvolvimento foliar em duas cultivares de oliveira estimado por duas categorias de modelos. Revista Brasileira de Meteorologia, v.29, p.505-514, 2014. https://doi.org/10.1590/0102778620140020

Martins, F. B.; Silva, J. C. da; Streck, N. A. Estimativa da temperaturabase para aparecimento de folhas e do filocrono em duas espécies de eucalipto na fase de muda. Revista Árvore, v.31, p.373381, 2007. https://doi.org/10.1590/S0100-67622007000300002

Martins, F. B.; Streck, N. A. Aparecimento de folhas em mudas de eucalipto estimado por dois modelos. Pesquisa Agropecuária Brasileira, v.42, p.1091-1100, 2007. https://doi.org/10.1590/S0100204X2007000800005 
Monteiro, E. B.; Silva, C. C. da; Silva, A. C. da; Souza, A. P. de. Estimating emission of leaves seedlings Forest in different shading levels, at conditions of transition Amazon-Cerrado, Brazil. American Journal of Plant Sciences, v.5, p.2330-2341, 2014. https://doi.org/10.4236/ajps.2014.515247

Pereira, F. M.; Kavati, R. Contribuição da pesquisa científica brasileira no desenvolvimento de algumas frutíferas de clima subtropical. Revista Brasileira de Fruticultura, v.33, p.92-108, 2011. https://doi.org/10.1590/S0100-29452011000500013

Sena, C. M. de; Gariglio, M. A. Sementes florestais: Colheita, beneficiamento e armazenamento. Natal: MMA, 2008. 28p.

Silva, J. C. B. da; Cândido Junior, J. F.; Vogel, H. F.; Campos, J. B. Dispersão por aves de Psidium guajava L. (Myrtaceae) em ambiente ripário na bacia do rio Paraná, Brasil. Semina: Ciências Biológicas e da Saúde, v.34, p.195-204, 2013. https:// doi.org/10.5433/1679-0367.2013v34n2p195

Souza, P. M. B. de; Martins, F. B. Estimativa da temperatura basal inferior para as cultivares de oliveira Grappolo e Maria da Fé. Revista Brasileira de Meteorologia, v.29, p.307-313, 2014. https:// doi.org/10.1590/S0102-77862014000200013
Statsoft Inc. Statistica for windows (data analysis softwares system), version 8.0. Computer program manual, Quick Reference. Tulsa: Statsoft, Inc., 2008. 298p.

Streck, N. A.; Lago, I.; Paula, F. L. M. de; Bisognin, D. A.; Heldwein, A. B. Improving predictions of leaf appearance in field grown potato. Scientia Agrícola, v.64, p.12-18, 2007. https://doi.org/10.1590/ S0103-90162007000100002

Velho, A. C.; Amarante, C. V. T. do; Argenta, L. C.; Steffens, C. A. Influência da temperatura de armazenamento na qualidade pós-colheita de goiabas serranas. Revista Brasileira de Fruticultura, v.33, p.14-20, 2011. https://doi.org/10.1590/S010029452011005000016

Wang, E.; Engel, T. Simulation of phenological development of wheat crops. Agricultural Systems, v.58, p.1-24, 1998. https:// doi.org/10.1016/S0308-521X(98)00028-6

Yang, S.; Logan, J.; Coffey, D. L. Mathematical formulae for calculating the base temperature for growing degree days. Agricultural and Forest Meteorology, v.75, p.61-74, 1995. https://doi. org/10.1016/0168-1923(94)02185-M 